\title{
A STUDY ON CUSTOMER SATISFACTION ON PUBLIC DISTRIBUTION SYSTEM IN PUNE CITY
}

\section{SHEETAL A. KHANDRE \& LALIT B. GOLDE}

Maharashtra, India

India's Public Distribution System (PDS) is the biggest and very important distribution network of its brand in the world. PDS was established around World War II as a wartime allowance measure. Earlier than the 1960s, allocation during PDS was normally dependent relative on imports of food grains. It was lengthened in the 1960s as an answer to the food shortages of the time, consequently, the government set up the Agriculture Prices Commission and the Food Corporation of India to progress domestic procurement and cargo space of food grains for PDS. In the 1970s, PDS had developed into a worldwide scheme for the allocation of subsidized food. In the 1990s, the scheme was refurbish to improve access of food grains to people in mountainous and unapproachable areas, and to goal the poor.

The paper is regarding the study of PDS in Pune. It describes about the satisfaction of consumers consuming ration.

KEYWORD: Public Distribution System \& BPL
\end{abstract}

Received: Apr 20, 2017; Accepted: May 15, 2017; Published: Jun 02, 2017; Paper Id.: IJECRJUN20173

\section{INTRODUCTION}

Public Distribution System (PDS)

Indian food security system is recognized through the Government of India under Ministry of consumers Affair's Food and Public Distribution and managed together with the state government of India. It distributes subsidized food and non-food items for India's poor. This method was introduced in India on June 1997. The important commodities distributed include the important food grains, such as wheat, rice, Sugar, and Kerosene, through a network of Public Distribution Shops (also known as ration shops) recognized in numerous states across the country. In PDS method, each family below the poverty line is eligible for $35 \mathrm{~kg}$ of rice or wheat each month, while a household more than the poverty line is allowed to $15 \mathrm{~kg}$ of food grain on a monthly basis.

A below poverty line (BPL) card holder is supposed to be given the specified $35 \mathrm{~kg}$ of food grain, and the card holder higher than the poverty line is supposed to be given $15 \mathrm{~kg}$ of food grain as per the rules of PDS. However, there are apprehensions about the competence of the allocation process.

\section{REVIEW OF RELATED STUDIES}

Ghuman et al. (2013) in their paper on the association and operation of PDS in Punjab, believe PDS as a helpful policy appliance in providing that significant merchandise to the underneath poverty line people. Punjab is the most important supplier in conditions of national manufacture of wheat and rice. In their study, they establish that in Punjab, almost $76 \%$ of the food particles were unfocused to the open market and another $13 \%$ were unfocused APL households. A meager $10 \%$ of the granule reached the BPL recipient. This paper presents the main 
leaks and weaknesses in the functioning of PDS in Punjab.

Jha et al. (2013a) accomplished a relative study of the Public Distribution System based on factors like food funding, income transfer and the participation of the poor. Three Indian states - Andhra Pradesh, Rajasthan and Maharashtra were selected for the study and primary data was composed of five hundred families from each of these three states. The study exposed that the agenda is not well besieged and the poor as well as the non-poor collect subsidy benefits. Improved network of Fair Price Shops, the upper margin of the PDS price with the bazaar price, sufficient supply, capable procurement, storage and allocation and prioritizing source of revenue increase occasions of the rural area's strength make certain food safety.

\section{OBJECTIVES OF THE STUDY}

The major objectives of this research are as follows:

- To study the quality of the products

- To study if the BPL card holders are getting the right amount of quantity

- To study the availability of products

- To identify the knowledge of BPL card holders.

\section{RESEARCH METHODOLOGY}

\section{Type of Research: Expressive Research}

Expressive research is used to describe individuality of a person or occurrence being studied. It does not answer questions about how/when/why the individuality occurred? Rather, it addresses the "what" question, i.e., what are the characteristics of the inhabitants or condition being studied?

\section{Research Tool}

The questionnaire consists of open ended and close ended questions. A form containing a set of questions was submitted to the BPL card holders to gain statistical information. Structured questions in which possible answers are suggested and they had to choose from the given options.

\section{Sampling Method}

Possibility Sampling is a sampling technique, wherein the samples are assembled in a process that gives all the individuals in the population, who have equal chances of being selected.

\section{Sampling Unit}

We considered BPL card holders from the Pune district as sampling unit.

\section{Size of Sample}

We considered 100 BPL card holders and 10 Shopkeepers for our project analysis.

Data Type

Data collected is of the Primary Type. 
Primary Data is data which are collected through a questionnaire.

\section{DATA ANALYSIS}

Are you satisfied with the Quality of Product?

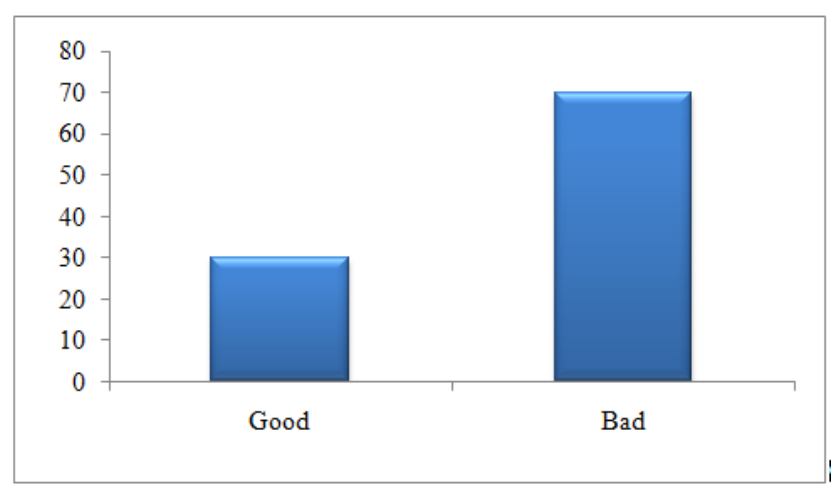

Figure 1: Consumer Point of View

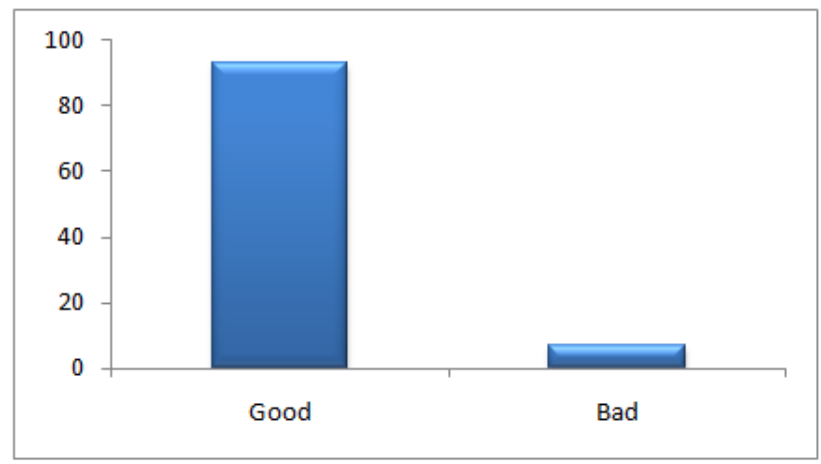

Figure 2: Shopkeeper Point of View

Is the Products Available of All Time?

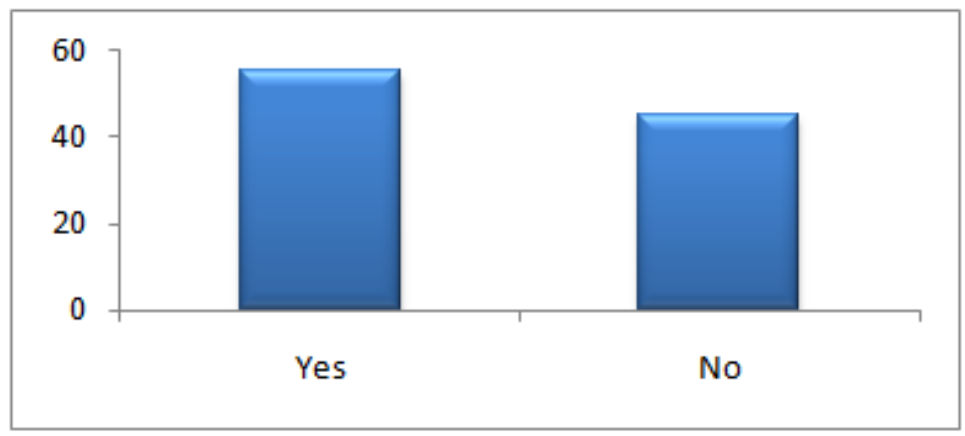

Figure 3: Consumer Point of View 


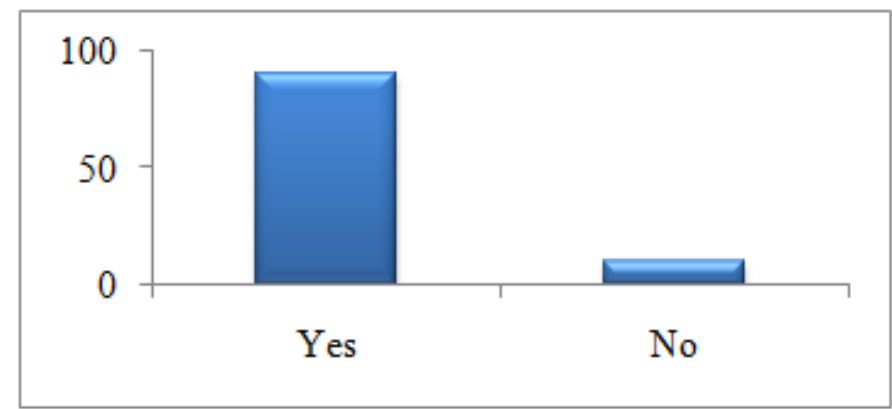

Figure 4: Shopkeeper Point of view

Have you seen any Malpractices done by the Shopkeeper?

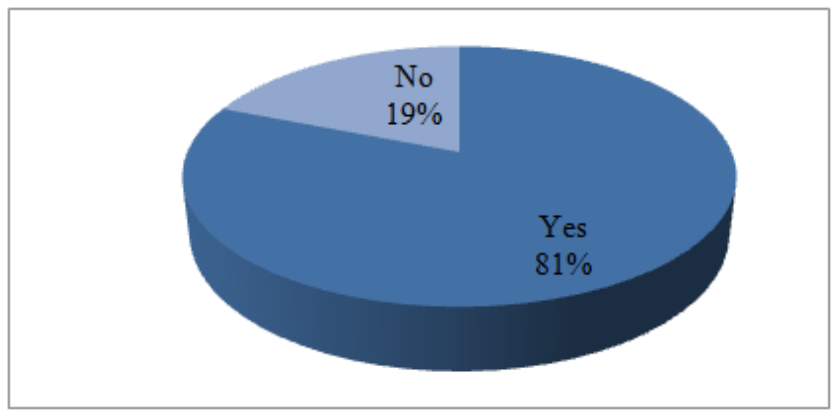

Figure 5

How much do you Rate the Overall Experience?

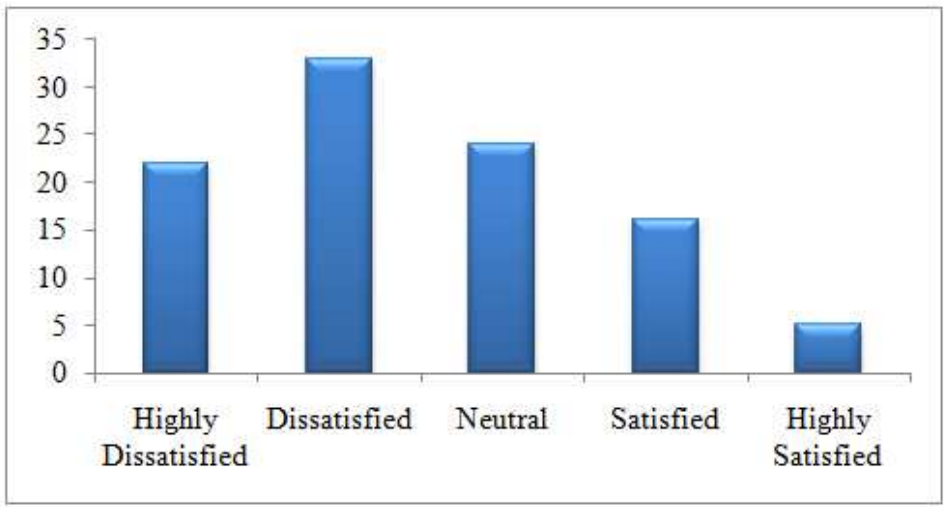

Figure 6

\section{FINDINGS}

- $\quad$ There is unavailability of food grains in the shop

- The quality of food grains is not up to the mark

- There are many instances of adulteration of goods

- There is an insufficient quantity of grains in the shop

- They are not satisfied with the service of ration shop 


\section{CONCLUSIONS}

- Quality of product is the worst: the BPL card holders are not at all satisfied with the quality.

- Unavailability of products on time: there are many instances, when the products are not available in the shop.

- Malpractices done by shopkeeper: Some shopkeepers do the malpractices to earn more profit such as use of magnet etc.

- Adulteration in products: They mix low quality of food to increase the quantity.

- Unaware about the allotment of products: BPL card holders are not aware of how much quantity of grains they have been allotted by the government.

\section{SUGGESTIONS}

- Improvement of quality of product.

- $\quad$ Making products available on time.

- Creating awareness in public about the ration allowed as per family members.

\section{REFERENCES}

1. Abraham, K. (1991). Malfunctioning of the Public Distribution System: An Empirical Analysis. Vikalpa, 16(1), 43-50.

2. Ahluwalia, D. (1993). Public Distribution of Food in India: Coverage, targeting and leakages. Food Policy, 18(1), 33-54.

3. Arora, R. U. (2013). Food Subsidies for the Poor in India: Are they Working? Journal of Asian Public Policy, 6 (3).

4. Balakrishnan, P., \& Ramaswami, B. (1997). Quality of Public Distribution System: Why it Matters. Economic and Political Weekly, 162-165.

5. Dutta, B., \& Ramaswami, B. (2001). Targeting and Efficiency in the Public Distribution System: Case of Andhra Pradesh and Maharashtra. Economic and Political Weekly, 1524-1532.

6. Ghuman G. \& Dr. Dhiman P, (2013). Organization and Working of Public Distribution System A Study of Punjab. Indian Journal of Applied Research, Vol.3, Issue 4, 285-289.

7. Jha, R., Gaiha, R., Pandey, M. K., \& Kaicker, N. (2013). Food subsidy, Income Transfer and the Poor: A Comparative Analysis of the Public Distribution System in India's States. Journal of Policy Modeling, 35(6), 887-908. 
